\title{
PENILAIAN ERGONOMISITAS TENAGA KERJA DI UNIT DRUMPLANT PT. PERTAMINA (Persero) RU IV CILACAP TAHUN 2015
}

\author{
Ita Latiana Damayanti ${ }^{1)}$, Zaeni Budiono ${ }^{2)}$ \\ Jurusan Kesehatan Lingkungan, Politeknik Kesehatan Kemenkes Semarang, \\ Jl. Raya Baturaden KM 12 Purwokerto, Indonesia
}

\begin{abstract}
Abstrak
Unit Drumplant merupakan salah satu penunjang proses produksi di PT. Pertamina RU IV Cilacap yang berfungsi sebagai tempat drum manufacturing dan asphalt filling. Proses produksi menggunakan peralatan terpadu menimbulkan banyak resiko. Tujuan penelitian ini yaitu untuk mengetahui kesesuaian antara antropometri tenaga kerja dengan perkakas kerja yang digunakan di Unit Drumplant PT. Pertamina (Persero) RU IV Cilacap. Jenis penelitian ini adalah deskriptifdengan pengamatan langsung dan pengukuran pada tenaga kerja dan perkakas kerja, Hasil penelitian menunjukkan bahwa dari 25 pekerja yang diukur , hanya 2 pekerja yang antropometri sesuai dengan perkakas kerja di Unit Drumplant PT. Pertamina (Persero) RU IV Cilacap, yaitu 8 \% ergonomis dan $92 \%$ tidak ergonomis. Sehingga dapat menyebabkan penyakit akibat kerja dan menurunnya produktifitas kerja. Berdasarkan hasil tersebut disimpulkan bahwa belum ada kesesuaian antara antropometri pekerja dengan perkakas kerja.Untuk mencegah menurunnya produktifitas kerja maka hendaknya disediakan alas untuk berdiri sehingga posisi kerja tidak terlalu pendek ke mesin yang tingginya dapat disesuaikan dengan jenis pekerjaan dan antropometri pekerja.Kemudian disediakan juga kursi pada tiap mesin produksi agar pekerja dapat duduk sejenak untuk mengurangi kelelahan akibat bekerja dengan posisi yang berdir terus menerus.
\end{abstract}

Kata kunci : Penilaian, Ergonomi, Antropometri Pekerja, Perkakas Kerja

\begin{abstract}
[Labor ergonomic assessment in the drumplant unit of PT. Pertamina (Ltd) RU IV Cilacap Year of 2015]Drumplant Unit is one of production process supporting unit in PT. Pertamina RU IV Cilacap which serves as a drum manufacturing and asphalt filling. The production process uses an integrated equipment pose many risks. The research objective was determining the compatibility labor anthropometric harmonization with working tools used in drumplant unit of PT. Pertamina (Ltd) RU IV Cilacap.This research design used was descriptive with observation and measurement of workers anthropometric and labor instruments anthropometric measurements (production engine at Drumplant Unit).The measurement results shows that from 25 workers, there were only two worker's anthropometry that suited with the working instruments in Drumplant Unit PT. Pertamina (Persero) RU IV Cilacap, for $8 \%$ and the rest 92\% were not ergonomic. That condition could cause working grievance and decreasing productivity.The research conclusion was; there was no conformity between workers anthropometric with working tools. In order prevent labor's productivity decrease, adjustable pedestal should be provided so that the working position will conform with the tool height. It was also expected to provide chair on each production machine so that workers can sit for a while to reduce fatigue caused by working on standing pose continuously.
\end{abstract}

Keywords : Assesment, Ergonomic, Worker Anthropometry, Working tools

\section{PENDAHULUAN}

Undang-Undang No. 36 tahun 2009 tentang Kesehatan pasal 164 disebutkan bahwa upaya kesehatan kerja ditujukan untuk melindungi pekerja agar hidup sehat dan terbebas dari gangguan kesehatan serta pengaruh buruk yang diakibatkan oleh pekerjaan meliputi pekerja di sektor formal dan informal. Bagi pengelola tempat kerja wajib mentaati standar kesehatan kerja dan menjamin lingkungan kerja yang sehat serta bertanggung jawab atas terjadinya kecelakaan kerja.

Keselamatan dan kesehatan kerja merupakan salah satu aspek perlindungan tenaga kerja sekaligus

1) Email : Italatiana_damayanti@yahoo.com

2) Email : pakzaeni@gmail.com melindungi aset perusahaan. Untuk memberikan perlindungan bagi tenaga kerja dapat dilakukan suatu upaya yaitu dengan melakukan pelayanan kesehatan seperti yang tercantum dalam Undang- Undang Nomor 36 tahun 2009 pasal 52 ayat 1 bahwa pelayanan kesehatan terdiri atas pelayanan kesehatan perseorangan dan kesehatan masyarakat. Pelayanan kesehatan sebagaimana yang dimaksud meliputi kegiatan pendekatan promotif, preventif, kuratif, dan rehabilitatif.Pelayanan preventif diberikan guna mencegah terjadinya penyakit akibat kerja, penyakit menular di lingkungan kerja dengan menciptakan kondisi pekerja dan mesin atau tempat kerja agar

Keslingmas Vol. 35 Hal. 86 - 151 Juni 2016 | 115 
ergonomis, menjaga kondisi fisik maupun lingkungan kerja yang memadai dan tidak menyebabkan sakit atau membahayakan pekerja serta menjaga pekerja tetap sehat.

Upaya untuk menciptakan kondisi pekerja dan mesin atau tempat kerja agar ergonomis, kondisi yang dimaksud dapat diartikan bahwa harus adanya keserasian antara pekerja dengan mesin atau perkakas kerja agar tenaga kerja dapat terhindar dari kecelakaan kerja. Ketentuan tersebut juga terdapat pada Undang- Undang Republik Indonesia Nomor 1 Tahun 1970 tentang keselamatan kerja menyebutkan bahwa syarat-syarat keselamatan kerja yaitu salah satunya memperoleh keserasian antara tenaga kerja, alat kerja, lingkungan cara dan proses kerjanya.

Peralatan kerja dan mesin perlu diserasikan dengan ukuran tubuh tenaga kerja untuk tujuan meraih hasil kerja secara kualitatif dan kuantitatif memuaskan serta tenaga kerja merasakan kemudahan dalam melakukan pekerjaannya. Atas landasan konsep demikian berkembang ilmu yang disebut Antropometri, yaitu ilmu tentang ukuran tubuh dan segmen - segmennya, baik dalam keadaan statis maupun dinamis yang sangat besar manfaatnya bagi keperluan pelaksanaan dengan tujuan agar tenaga kerja sehat dan produktif bekerja.(Suma'mur, 2009, h.322).

PT. Pertamina (Persero) Refinery Unit IV Cilacap Indonesia merupakan Unit Operasi Direktorat Pengolahan terbesar dan terlengkap hasil produksinya di Indonesia.Unit Drumplant merupakan salah satu unit pendukung di PT. Pertamina (Persero) RU IV Cilacap yang berada di bawah pengawasan Manager Production II, drumplant berfungsi sebagai pembuat drum untuk pendistribusian asphalt.Tujuan penelitian ingin mengetahui kesesuaian antropometri pekerja dengan perkakas kerja di Unit Drumplant PT. Pertamina (Persero) RU IV Cilacap.

\section{BAHAN DAN METODE}

Jenis penelitian ini adalah deskriptif.Subjek penelitian ini adalah pekerja yang berjumlah 25 orang dan perkakas kerja yang berjumlah 11 buah mesin produksi di Unit Drumpalnt PT. Pertamina (Persero) RU IV Cilacap. Pengumpulan data dilakukan dengan cara pengamatan langsung dan pengukuran antropometri pekerja serta perkakas kerja.

\section{III.HASIL DAN PEMBAHASAN}

Unit Drumplant merupakan salah satu unit pendukung di PT. Pertamina (Persero) RU IV Cilacap yang berada di bawah pengawasan Manager Production II, drumplant berfungsi sebagai pembuat drum untuk pendistribusian asphalt. Proses pembuatan drum dilakukan di dalam gedung yang kondisinya sangat bising dan getarannya tinggi sehingga pada saat pekerja masuk ke dalam gedung tersebut harus menggunakan Alat Pelindung Diri (APD) berupa ear plug maupun ear muff untuk mengurangi paparan kebisingan terhadap pekerja kemudian pekerjaan dilakukan secara bergilir setiap 1 jam sekali.

Proses produksi pembuatan ready drum dari bahan bakusteel sheet (pelat baja) dengan menggunakan mesin-mesin terpadu sampai dengan proses pengecatan (painting). Pekerjaan dilaksanakan setiap hari dengan target produksi sesuai pesanan. Pada umumnya produksi yang diminta 1200 drum/hari. Pekerja pada unit ini tidak meiliki jam kerja yang pasti, dikarenakan semua pekerjaan didasarkan pada hasil produksi. Jika jumlah ready drum sudah memenuhi target maka pekerjaan dianggap selesai. Waktu istirahat yang ditetapkan adalah pekerjaan dilakukan secara bergiliran setiap satu jam sekali, setiap mesin dipegang oleh 2-4 operator tergantung pada jenis mesinnya.

Pada perkakas kerja dilakukan pengukuran tinggi landasan mesin yang hasilnya adalah Grinder Machine $103 \mathrm{~cm}$, Tree Roll Machine $81 \mathrm{~cm}$, Spot Welder $85 \mathrm{~cm}$, Seam Welder $88 \mathrm{~cm}$, Flanging Machine $93 \mathrm{~cm}$, Corrugatting Machine $92 \mathrm{~cm}$, Vertical Double Seamer 82 cm, Leak Tester Machine 99 cm, Painting Machine 121 cm, 150 Ton Press Machine I 112 cm, 60 Ton Press Machine I\&II 98 $\mathrm{cm}$ dan Cutting Machine $98 \mathrm{~cm}$. sedangkan rata-rata tinggi landasan perkakas kerja di Unit Drumplant adalah $96,15 \mathrm{~cm}$.

Hasil pengukuran 25 pekerja yang ada pada unit drumplant menunjukkan tinggi badan maksimal adalah $173 \mathrm{~cm}$, sedangkan tinggi badan minimal 154 $\mathrm{cm}$, nilai rata-rata yang didapat dari tinggi badan pekerja adalah 164,64 cm. Untuk tinggi bahu berdiri nilai maksimalnya $147 \mathrm{~cm}$ dan nilai minimalnya 127 $\mathrm{cm}$, nilai rata-rata yang didapat dari tinggi bahu 137,28 cm. Untuk tinggi siku berdiri nilai maksimalnya $111 \mathrm{~cm}$ dan nilai minimalnya $94 \mathrm{~cm}$. Nilai rata-rata tinggi siku berdiri $102,08 \mathrm{~cm}$. Untuk tinggi pinggul maksimalnya $102 \mathrm{~cm}$ dan nilai minimalnya $90 \mathrm{~cm}$. Nilai rata-rata tinggi pinggul yaitu 96,96 cm. Untuk depa maksimalnya $169 \mathrm{~cm}$ dan minimalnya $157 \mathrm{~cm}$. Nilai rata-rata depa yaitu 164,72.Kemudian dengan melihat kesesuaian antara antropometri pekerja dengan perkakas kerja di Unit Drumplant PT. Pertamina (Persero) RU IV Cilacap maka dapat disimpulkan bahwa terdapat 2 pekerja yang ergonomis, sedangkan terdapat 23 pekerja yang tidak ergonomis. Pada sikap kerja berdiri ini disediakan alas kaki agar posisi kerja tidak terlalu pendek ke mesin yang disesuaikan dengan jenis pekerjaan dan antropometri pekerja. Sedangkan untuk mengurangi kelelahan akibat bekerja dengan posisi berdiri secara terus menerus dapat dilakukan dengan pemberian kursi pada spot tertentu agar pekerja dapat duduk sejenak untuk beristirahat.

\section{IV.SIMPULAN}

Unit Drumplant merupakan salah satu unit pendukung di PT. Pertamina (Persero) RU IV Cilacap yang berada di bawah pengawasan Manager Production II, drumplant berfungsi sebagai pembuat 
drum untuk pendistribusian asphalt. Rata-rata antropometri dari 25 pekerja yang diukur didapatkan hasil Tinggi Badan 164,64 cm, Tinggi Bahu 137,28 cm , Tinggi Siku 102,08 cm, Tinggi Pinggul 96,96 cm dan Depa 164,72 cm. Rata-rata tinggi landasan dari 11 perkakas kerja adalah 96,15 cm.Dari 25 pekerja hanya 2 pekerja yang dapat dikatakan sesuai dengan perkakas kerja yang digunakan, $8 \%$ ergonomis dan $92 \%$ tidak ergonomis.

\section{DAFTAR PUSTAKA}

Cahyono, Tri. (2012). Pedoman Penulisan Proposal Penelitian dan Karya Tulis Ilmiah/ Skripsi (Edisi Revisi Kedua), Purwokerto : Kementrian Kesehatan Kemenkes Semarang Jurusan Kesehatan Lingkungan.

M, Soeripto, (2008). Hygiene Industri. Jakarta: Penerbit buku FKUI.

Nurmianto, Eko. (1996). Ergonomi Konsep Dasar dan Aplikasinya : ITS Surabaya

Ramlan, Djamaluddin. (2006). Dasar - Dasar Kesehatan Kerja, Purwokerto : Kementrian Kesehatan RI Politeknik Kesehatan Kemenkes Semarang Jurusan Kesehatan Lingkungan.

Ridley, John. (2006). Ikhtisar Kesehatan dan Keselamatan Kerja.Jakarta : Penerbit buku Erlangga.
Santoso, Gempur. (2004), Ergonomi Manusia, peralatan dan Lingkungan.Jakarta : Prestasi Pustaka Jakarta

Sari, Jihan Mutiara. (2012). Studi Tentang Penerapan Ergonomi Perkakas Kerja, Purwokerto : Kementrian Kesehatan Kemenkes Semarang Jurusan Kesehatan Lingkungan.

Suma'mur, P.K. (1989). Ergonomi Untuk Produktivitas Kerja. Jakarta : CV. Haji Masagung.

Suma'mur, P.K. (1994). Higiene Perusahan dan Kesehatan Kerja. Jakarta, CV. Haji Masagung.

Suma'mur, P.K. (2009). Higiene Perusahaan dan Kesehatan Kerja. Jakarta: CV. Sagung Seto.

Tarwaka, Bakri S, Sudiajeng L. (2004). Ergonomi untuk Keselamatan, Kesehatan Kerja dan Produktivitas. Surakarta: UNIBA PRESS.pp: 41-42.

Undang-Undang Republik Indonesia Nomor 1 Tahun 1970 Tentang Keselamatan Kerja. Jakarta: Presiden.

Undang-Undang Republik Indonesia Nomor 36 Tahun 2009 Tentang Kesehatan.Jakarta: Presiden. 